\title{
DENDROCHRONOLOGICAL DATING IN EGYPT: WORK ACCOMPLISHED AND FUTURE PROSPECTS
}

\author{
PETER IAN KUNIHOLM ${ }^{1 *}$, MARYANNE NEWTON ${ }^{2}$, HEND SHERBINY ${ }^{1}$, and HUSSEIN BASSIR ${ }^{1}$
}

${ }^{1}$ Laboratory of Tree-Ring Research, University of Arizona, 1215 E. Lowell Street, Tucson, AZ 85721, USA.

${ }^{2}$ Middleburg, VA 20018, USA.

*Corresponding author: pik@1trr.arizona.edu.

\begin{abstract}
We assess the state of and potential for expansion of dendroarchaeological research in Egypt. We also report previously unpublished findings, which we hope will assist with the new effort in constructing tree-ring chronologies in Egypt. In doing so, we explain briefly some of the problems and potential of the future enterprise.

Keywords: dendroarchaeology, Egypt, Egyptology, chronology, wood, tree rings, cedar, juniper, crossdating.
\end{abstract}

\section{INTRODUCTION}

\section{Nature and Origin of the Material}

Dendrochronology, the science of dating using tree rings, was born in the arid American Southwest, an environment not unlike that of the Eastern Mediterranean. The use of tree-ring research to understand the ecological contexts and the chronology of archaeological phenomena in the American Southwest was so successful that it has since been emulated worldwide (Douglass 1929; Haury 1935, 1962, 1994; Judd 1962; Webb 1983; Schweingruber 1988; Dean 1996; Bannister et al. 1998; Nash 1998, 1999, 2008; Nash and Dean 2005; Reid and Whittlesey 2005; Touchan and Hughes 2009; Speer 2010; Cowie 2013). As the research methodology has been repeated in multiple archaeological contexts around the world, dendroarchaeology has become a discipline in its own right. In the Near East and Mediterranean, considerable progress has been made in constructing long tree-ring chronologies and using tree rings to date artifacts and buildings (Bannister 1970; Kuniholm and Striker 1987; Kuniholm 1996, 2000; Kuniholm et al. 1996; Touchan et al. 1998; Cichocki et al. 2004; Rich 2013). However, to date, little dendrochronological progress has been made in Egypt.

For chronological sequencing, Egyptologists still rely heavily on chronologies based on ancient Egyptian sources: the Royal Annals, the Royal Canon of Turin, the King Lists, and Manetho's Aigyptiaka (see Hornung et al. 2006), and Classical and Near Eastern textual evidence (for Near Eastern texts, see Kitchen 2013). Scientific dating techniques such as dendrochronology and radiocarbon dating (Bronk Ramsey 2013) are still not widely used or properly applied. In the case of dendrochronology, this is because the technique is not widely known among Egyptian scholars, and with very few published demonstrations of how it could be used in Egypt, the potential of "lesser" material (structural timbers, badly degraded samples) to contribute to dendroarchaeological research has not yet been realized. We note that it was the objections of the Egyptologists - among others - to the first ${ }^{14} \mathrm{C}$ curve, which resulted in research that led to a modified half-life for the ${ }^{14} \mathrm{C}$ curve and then to the first tree-ring calibrated ${ }^{14} \mathrm{C}$ curve. Although many Egyptologists believe that Egyptian chronology is stable and accurate, multiple disagreements in the literature show that is not really the case (Shaw 2000b; Hornung et al. 2006; Kitchen 2013) despite ongoing improvements (Kitchen 2013). The New Kingdom chronology is fairly stable, but the Second Intermediate Period, the Middle Kingdom, the First Intermediate Period, and the Old Kingdom have chronological problems, with accuracy diminishing as one goes further backward in time. ${ }^{1}$ Astronomical sightings (e.g. the heliacal rising of Sirius) are claimed by some to be accurate, but nobody knows where the sightings were made or whether the sightings were all from the same spot. A glance at Ryholt's (1997) drawings of the remaining fragments of the king list on the Turin Papyrus shows how many gaps there are. Also problematical are the possibilities of co-regencies or gaps between reigns or rulers whose names are missing altogetherespecially in the Second Intermediate Period - so that the kind of precision provided by tree-ring dates of the American Southwest is lacking. A further complicating factor is the need to reconcile the Egyptian with the Mesopotamian chronology, which has its own problems. ${ }^{2}$

1. At a symposium to celebrate the 60th anniversary of the Oriental Institute in Chicago, the late Klaus Baer said he could go up or down 200 years for the Old Kingdom, and it would not bother him a bit.

2. At that same symposium, the late Dietz Edzard said he had no faith whatever in the Venus "Doublets," which are supposed to provide firm dates for Mesopotamia.

Center for Mediterranean Archaeology and the Environment (CMATE) Special Issue

Joint publication of Radiocarbon and Tree-Ring Research 
Table 1. Uses of wood in ancient Egypt.

\begin{tabular}{|c|c|c|c|c|c|c|c|}
\hline Wooden remains & $\begin{array}{l}\text { Predynastic } \\
\text { Period }\end{array}$ & $\begin{array}{l}\text { Archaic Period (First and } \\
\text { Second Dynasties) }\end{array}$ & $\begin{array}{l}\text { Old } \\
\text { Kingdom }\end{array}$ & $\begin{array}{l}\text { Middle } \\
\text { Kingdom }\end{array}$ & $\begin{array}{l}\text { New } \\
\text { Kingdom }\end{array}$ & $\begin{array}{l}\text { Third Inter- } \\
\text { mediate Period }\end{array}$ & $\begin{array}{l}\text { Late } \\
\text { Period }\end{array}$ \\
\hline Structural timber & $\mathrm{X}$ & & $\mathrm{X}$ & & $X$ & & $\mathrm{X}$ \\
\hline Coffins & $\mathrm{X}$ & $\mathrm{X}$ & $\mathrm{X}$ & $\mathrm{X}$ & $\mathrm{X}$ & $\mathrm{X}$ & $\mathrm{X}$ \\
\hline Statues & & $\mathrm{X}$ & $\mathrm{X}$ & $\mathrm{X}$ & $\mathrm{X}$ & & \\
\hline Furniture & & $\mathrm{X}$ & $\mathrm{X}$ & $\mathrm{X}$ & $\mathrm{X}$ & $\mathrm{X}$ & $\mathrm{X}$ \\
\hline Ships and boats & $\mathrm{X}$ & $\mathrm{X}$ & $\mathrm{X}$ & $\mathrm{X}$ & $\mathrm{X}$ & & \\
\hline Minor objects & $\mathrm{X}$ & $\mathrm{X}$ & $\mathrm{X}$ & $\mathrm{X}$ & $\mathrm{X}$ & $\mathrm{X}$ & $\mathrm{X}$ \\
\hline
\end{tabular}

\section{Wood and Its Uses in Ancient Egypt}

Bryant Bannister (1963) said that in order for dendrochronology to be carried out three conditions must first be met. The ancient inhabitants of a region must have used wood in quantity in their constructions. The wood must be crossdatable, and enough of it must be preserved for proper study. All three of these conditions can be met - in certain circumstances, as outlined below - in Egypt.

Wood was a major resource in the civilizations of the ancient Near East (Thirgood 1981; Gilbert 1995; Hepper 1996; Kuniholm 1997), including Egypt, thereby fulfilling Bannister's first criterion. Because of the lack of adequate rainfall, Egypt itself produced few large trees and so relied on imported wood. Typical of local woods are sycamore fig (Ficus sycomorus) nht (Hannig 2006; Gale et al. 2009), the Nile acacia (Acacia nilot-

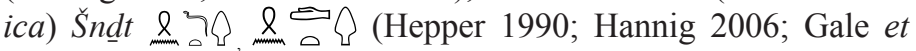
al. 2009), tamarisk (Tamarix nilotica and Tamarix aphylla) jsr

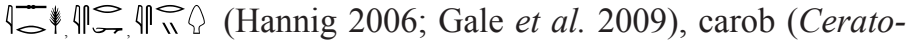
nia siliqua) ndm (Lucas and Harris 1962; Baum 1988; Hannig 2006; Gale et al. 2009), doum palm (Hyphaene thebaica) m3m3 y 3来, det. Q. 2000; Hannig 2006; Gale et al. 2009), and date palm (Phoenix dactylifera) bnrt 䟭 (Greiss 1957; Baum 1988; Hannig 2006; Gale et al. 2009). These species usually produced poor quality wood with small lengths and cross-sections that limited the types of constructions in which they could be used (Killen 2001). The difficulty with these local types of wood is that if any part of their ring growth is caused by irrigation the climate signal will be hard to detect. The most common imported types of wood are cedar (Cedrus libani) \& 1962; Meiggs 1982; Nibbi 1987; Wilson 1997; Cichocki 2003; Hannig 2006; Gale et al. 2009), juniper from the Levant, and cypress (Cupressus sempervirens) (Lucas and Harris 1962; Hepper 1990; Gale et al. 2009). Although there is a debate whether $m r w$ or $\ulcorner\breve{S}$ is the word for cedar, on the deck of the Khufu boat I at Giza there is a box (as yet unidentified as to species) with an inscription that says "this box is made of meru-wood" (Lanny Bell, personal communication). It has been recently stated that $m r w$ is "a type of fir tree from Lebanon," probably "cedar of Lebanon," while `ک̌ is "fir wood" (Wilson 1997; El Gabry 2014). ${ }^{3}$

Wood was utilized in ancient Egypt in different ways, especially in the making of statues, coffins, and funeral boxes, and a variety of wooden items (Engelbach 1931; Oakley 1932; Gale et al. 2009; Deglin 2012; El Gabry 2014). Woodworking was among the advanced technologies in ancient Egypt (Oakley 1932; Lucas and Harris 1962; Killen 1994b, 2001, 2009; see Table 1).

To follow the model of Douglass, Bannister, and Southwestern archaeology in general (Douglass 1929; Haury 1935, 1962, 1994; Bannister 1962; Bannister and Robinson 1975, 1992; Dean 1978; Reid and Whittlesey 2005), the beginnings of a tree-ring record for Egypt should logically be rooted in trees that are growing in the larger region today (compare Dunwiddie 1979). If dendrochronological research is going to succeed in Egypt, it is most probably going to have to be with cedar and juniper, both longlived trees that grow next to each other in the mountains of Lebanon, the Taurus Mountains of Turkey's southern coast, and in Cyprus (Kuniholm et al. 2007). Juniper is less problematic (fewer missing rings) than cedar, and often when we have had pairs of chronologies from the same forest to compare, we have resorted to the juniper to solve the missing-ring problems with the cedar. Tree-ring patterns in Nilotic trees such as sycamore and tamarisk will depend on the water flow in neighboring canals rather than on prevailing climate. In most museum collections of Egyptian artifacts, one sees the word "wood" rather than proper species names (see e.g. Bassir 2013). It is not unusual for $95 \%$ or more of the artifacts to be acacia. Kuniholm has examined over 1000 samples of acacia for their dendrochronological potential without any success whatsoever. Ring boundaries are either invisible or practically invisible, and without identifying rings with precision dendrochronology simply does not work. Attempts to come up with a proper ring count have been unsuccessful from the time of A. E. Douglass

3. For extended discussions about various problems of identification of trees and timber in Mesopotamia - ethnographic, textual, philological, botanical, historical, dendrochronological—see Postgate and Powell (1992). 
on. ${ }^{4}$ On one of the sections Douglass collected in the 1930s from the Meidum Pyramid, a class of 10 students was tasked with establishing a ring count. They ended up with 10 different totals.

Although Lebanon, specifically Byblos, is generally thought to be the source for cedar wood found in Egypt, the Taurus Mountains and Cyprus are an equally rich source of the material in all periods. Plans are in the works to have two M.Sc. students survey the hitherto unexamined cedar stands in the Taurus from the Aegean Sea to Antioch, even to the Anti-Taurus, to develop appropriate profiles for each subregion for the last 700 or 800 years or more. The forest stands (Figure 4) that have been sampled so far-not imported from anywhere else, but still standing in place-crossdate with one another. The stand of some 400 surviving trees at Bcharré above Byblos has experienced so much human intervention in recent years that its overall signal is noisy, but there are centuries when it and the Taurus and Cyprus fit together quite satisfactorily. So far, there is no evidence for importation of Atlas cedar (Cedrus atlantica) from the far west of the Mediterranean.

We have a total of some 4000 years' worth of cedar chronologies from the Eastern Mediterranean and more than 6000 years' worth of juniper, ${ }^{5}$ though not all in one continuous sequence. As the next generation continues this work, it will be able to build on this with new material found in Egypt. But it must be remembered that any "Egyptian" chronology is going to be based on where those cedars originated, i.e. somewhere in the northeast corner of the Mediterranean (for a general overview of Egypt's history from the beginning until modern times, see Bassir 2012).

\section{Quantity and Preservation of the Material: Notes on the Mediterranean Timber Trade in Antiquity}

Timber has been traded in the Mediterranean for at least 5100 years, as early as the Predynastic Period in Egypt, before ca. 3000 BC (Shaw 2000b:480), evidenced by the finding of cedar charcoal at Maadi (ca. 4000-3200 BC) (Shaw 2000b:479) in the outskirts of Cairo (Rizkana and Seeher 1989; Nibbi 1990; Kuniholm et al. 2007). We have been accumulating physical evidence from a number of periods for the timber trade: in the Middle Ages west from the Black Sea and the Danube to Constantinople and Thessaloniki (Kuniholm et al., in press), in Venetian times south from the Alps to the Dalmatian coast and to Greece (Kuniholm et al. 2007) and the southern Levant (Lorentzen et al. 2011, 2012, in press), in Roman times south from the Alps to Pompeii and

\footnotetext{
4. When Kuniholm and Newton visited the Boston Museum of Fine Arts to check the proveniences of Schulman's samples (collected for Douglass), they noted that he had generally limited himself to Middle Kingdom material rather than to all of Pharaonic Egypt. Identifying the possibilities for crossdating was clearly on his mind. Also, in 1936 Douglass had the idea of employing W. S. Stallings on Egyptian dendrochronology, but this never came about (Nash 1999:203).

5. Having seen Lorentzen struggle with the Sinai wood, we are pessimistic about the dendrochronological potential for $J$. phoeniciae. There are too many missing rings. The Taurus junipers are far easier to deal with. B. Bannister (personal communication) says that the junipers northeast of the Four Corners of Arizona, Utah, Colorado, and New Mexico crossdate well, but the junipers a few miles away to the southwest do not crossdate at all — even with trees from the same stand.
}

Herculaneum (Kuniholm 2002), and in all periods-Predynastic through Ottoman - south to Egypt (Meiggs 1982; Rizkana and Seeher 1989; Kuniholm et al. 2007; Mikhail 2011). What this complexity of trade means is that dendrochronological dating in any of these target areas is not always going to be straightforward. Such possible links may often be hundreds of kilometers away.

Although the Dynasty IV Pharaoh Sneferu brags on the Palermo Stone about how he was the first to bring cedar from Lebanon-some 40 shiploads of it - every piece of wood in his tombchamber in the Bent Pyramid at Dahshur (collected half a century ago by Bryant Bannister) is juniper, possibly the first documented instance of fraud in international commerce (Kuniholm et al. 2007), and see Meiggs (1982) as well as Arnold (1991:Figures 5.24 and 5.25) for an image [captioned there as cedar] of the juniper timbers in the tomb-chamber at Dahshur. ${ }^{6}$

Dieter and Dorothea Arnold (personal communication) say that typical 19th century excavation notebooks in Egypt record that a wooden coffin a day was given to the cook for hot water and cooking. How many of these coffins were cedar ${ }^{7}$ is anybody's guess. In spite of this unfortunate practice, Egyptological collections still have wood in quantity, not just the more elegant samples on display but the less glamorous - but therefore possibly drillable or sawable - samples in the reserve collections. The prospect of scanning objects photographically to measure the rings as attempted (unsuccessfully) by Cichocki is daunting. Because some cedar rings can be as small as $0.01 \mathrm{~mm}$, a superficial examination of the surface of the object does not provide the needed resolution. Photographs, after all, cannot be sanded and polished.

A notable exception to the inadequacy of the scanning effort is the cedar plaque of Hathor in the Metropolitan Museum (Figure 1). Because she was neither painted nor stuccoed, and because the plank was cut radially, the rings could be measured with precision. ${ }^{8}$ When wood from that century becomes available for comparison, she should be datable.

In more recent centuries, for the last 300 years of the Ottoman Empire, there was a brisk exchange of Anatolian timber (including cedar) for Egyptian grain (Mikhail 2011), summed up in the three volumes of Ottoman forestry documents published by the Çevre ve Orman Bakanlığı (1999-2003). There are more Ottoman forestry documents in the Istanbul archives, which await translation. We suspect that a thorough investigation of the Islamic period monuments - religious, civil, and military - in Cairo will yield the necessary cedarwood or juniper wood for this research. Colleagues in the Antiquities Service and in the Awqaf

6. From these junipers in the Bent Pyramid, we have a 351-year chronology, which is earlier than anything available for comparison from Anatolia. For cedar in general, see Rich (2013), updating the work of the late J. P. Brown (1969), and see also the papers in the First International Cedar Symposium (Turkish Forestry Research Institute 1990)

7. As far as we know, nobody has made a serious investigation as to whether the use of cedar for a coffin had anything to do with the status of the deceased.

8. Hathor was measured twice by two of us with identical results. 


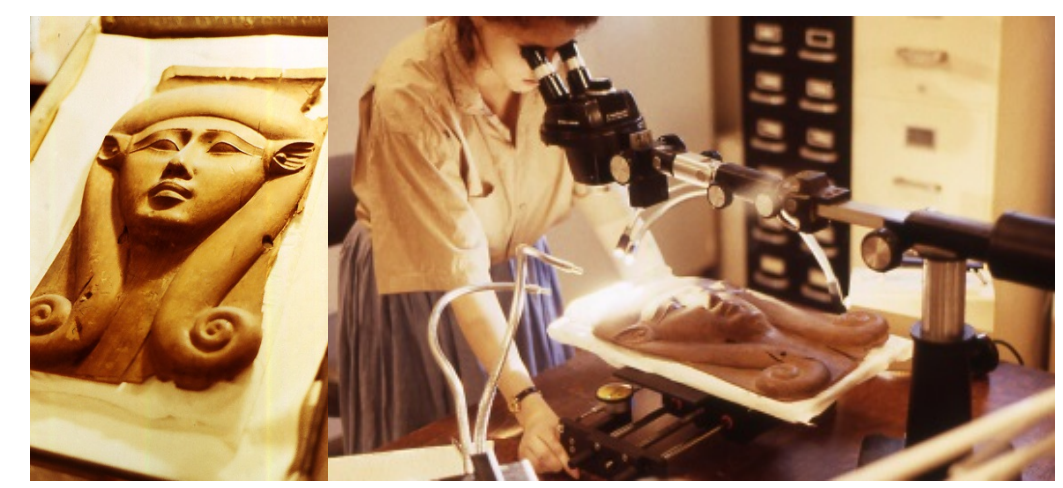

Figure 1. A plaque (capital face) of the goddess Hathor, Dynasty XXX (just before Alexander), in the Metropolitan Museum of Art in New York. Inv. 89.2.214, dimensions: $44.8 \times 26.7 \mathrm{~cm}$. Gift, MMA, Egyptian Collection, 1898, no. 36. Cedrus sp. See MMA Guide (1983) p. 106, fig. 48. On the right, Maryanne Newton measures the 129 rings without doing damage to Hathor's complexion. No 4th century $\mathrm{BC}$ cedar chronology yet exists against which to try to date her. Photograph P. I. Kuniholm.

(responsible for administering and maintaining all religious structures) should help gain an entrée. ${ }^{9}$ Not to be overlooked are the authorities in charge of highway-building, dam-building, land reclamation, canalization, and the like. If they, too, can be alerted as to the significance of any wooden material in their jurisdiction, this as well will be of importance. One anecdote as to why this will be important should suffice.

A single Directorate is not always on the qui vive about the importance of such material. A number of decades ago, the Lebanese highway department found an enormous cedar log in a landslide near one of their highways. Somebody was clever enough to bring the log to the American University of Beirut campus where it now resides under a shed roof. Some years ago, Ramzi Touchan of the LTRR was able to take a couple of increment cores from it. He then had a section ${ }^{14} \mathrm{C}$ dated and was informed that it was of no archaeological interest whatever since it was from 7500 years ago (R. Touchan, personal communication). His informant did not know that a date from 7500 years ago is of considerable archaeological significance because that is the time of the transition from the Neolithic to the Chalcolithic. So, future researchers would be well advised to begin with a certain amount of evangelism among the various Directorates. Arabic translations of some of the pertinent dendrochronological literature, as our Egyptian archaeological colleagues have proposed to produce, would be a big help.

\section{Is "Long-Distance" Crossdating Possible?}

Some readers may find it difficult to entertain the notion that a wooden object found in Egypt can be dated on the basis of comparing its ring patterns with Turkish material.

\section{Example One: Ottoman}

In her recent dissertation, Brita Lorentzen (2013) found that the trimmed cedar floorboards (with an end date of 1811) of the

\footnotetext{
9. Ottoman and Mameluke structures or objects are not likely to be as controversial as Pharaonic objects. If we succeed in getting firm dates, the scholars of the Bronze Age will get the message about the possibilities for their period.
}

Ottoman police station or kishle in Jaffa, in the southern Levant matched the cedar and juniper tree rings from the Taurus Mountains. The best fit was with the Çiğlikara Forest above Elmal, northwest of Antalya. There were other significant fits with forests ranging from Bcharré, Lebanon, to Rhodes and even east Crete, but the best bet is that this was an export from Antalya. Her date also matches the historical record of construction in 1886/7. Given the size of the exterior rings, less than $1 \mathrm{~cm}$ of wood need have been trimmed off in order to account for the missing 75 years.

\section{Example Two: Roman and Medieval}

At Herculaneum and Pompeii, we have found imported Alpine spruce and fir (Kuniholm 2002). In Dubrovnik, we found Alpine fir that matches the profile of the Black Forest. Alpine larch is found in Hg. Paraskevi, a Crusader church in Chalkis on the island of Euboea, Greece (Kuniholm et al. 2007), also in al-Aqsa Mosque in Jerusalem (Lorentzen 2013). Black Sea oak is found routinely in Constantinople/Istanbul and in churches, mosques, and fortifications in Thessaloniki (Kuniholm et al., in press).

\section{Example Three: Bronze Age, the "Near Absolute" Chronology}

For the Bronze Age and Iron Age, we have an extended, near-absolute tree-ring chronology mainly from Gordion/Porsuk/ Kültepe/Acemhöyük/Karahöyük-Konya, mostly juniper but with some cedar and occasional pines (Kuniholm 1977; Kuniholm and Newton 1990, 2011; Manning et al. 2001; Newton and Kuniholm 2004; Kuniholm et al. 2005). In a perfect world, we would try to keep all the species separate, but given the gaps we have and the amount of time we are trying to cover, we have been forced to combine species. The graph in Figure 2 (Newton and Kuniholm 2004) of the first half of a 2009-year floating chronology shows how complicated this 40 -year exercise was. The wood was not excavated in any sort of logical or helpful order, nor is it now placed where we first thought it ought to be. We collected what we could when it was convenient for the excavators and when we could meet them on site. 


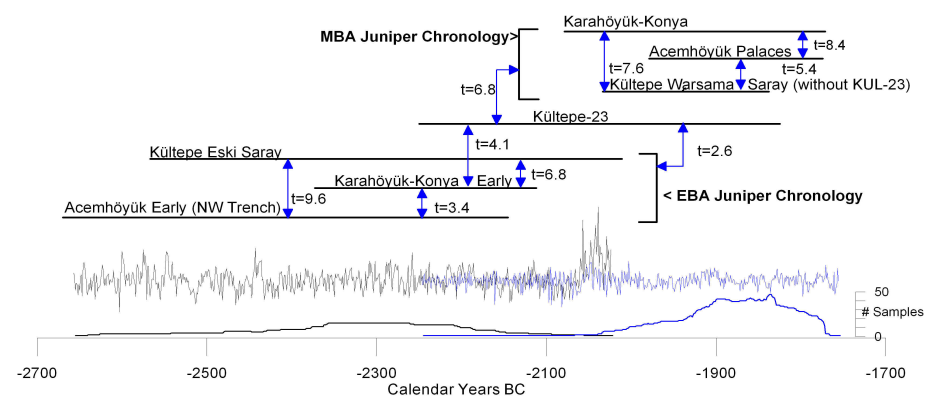

Figure 2. Early half of a 2009-year tree-ring chronology from juniper, cedar, and pine, almost all of it constructed from carbonized timbers that were preserved after violent conflagrations.

The archaeological sites represented above on the graph are on the central Anatolian Plateau in countryside that is today pretty much treeless (other than the willows and poplars that grow along the relatively few water courses). The huge, mudbrick, half-timberframed, burned palatial buildings at Acemhöyük (from which we have 287 carbonized samples) south of the Great Salt Lake (Tuz Gölü) and Kültepe (from which we have 88 carbonized samples) just north of Kayseri (Newton and Kuniholm 2004, with references to earlier publications) had an estimated minimum of 2000 trees per building. These numbers were arrived at on site during discussions with the excavators and their architects. So little of the palace at Karahöyük (67 carbonized samples) on the western outskirts of modern-day Konya has been exposed that a similar estimate is impossible. These trees, mostly juniper, cedar, and pine, would have been brought to these sites, presumably by oxcart, from various forests along the Taurus Mountain chain, as they were to the Seljuk monuments in Konya. This implies a road system and political control over the countryside in the 18th century BC. Noticeable variations in the tree-ring patterns within each site imply also that a variety of forests along the Taurus chain were the sources of the timber. We propose that some of the "Egyptian" cedars that we have dated also originated somewhere in these same mountains (see discussion below).

\section{Is Interspecies Crossdating Legitimate?}

This is a good - and reasonable-question. We have found good fits from modern forests for the last 6 to 8 centuries-especially when the overlap is long - between one species and another, notably oak versus pine and juniper (Kuniholm 1996: Figure 3, reproduced herein as Figure 3). The terminal ring was present for each core or section and there was no question about the end date when we sampled each tree. ${ }^{10}$ But dendrochronology is more than just numbers (measured widths): comparisons of the morphology of individual rings, the thickness and density of the latewood cells, and aberrations at the end of the growing season, for example, are things that we take into account when crossdating but that do not show up on simple $x-y$ graphs.

10. For comment on the various statistical tests (and their relative usefulness) that we use to confirm the visual fits, see Kuniholm and Newton (2011).

\begin{tabular}{|l|c|c|c|c|}
\hline \multicolumn{1}{|c|}{ Species } & $\begin{array}{c}\text { t-score } \\
\text { (Parametric) }\end{array}$ & $\begin{array}{c}\text { Years of overlap } \\
(\mathrm{n}=)\end{array}$ & $\begin{array}{c}\text { Trend Coefficient } \\
\text { (Non-parametric) }\end{array}$ & $\begin{array}{c}\text { D-score } \\
{[1-\text {-score } \text { *(trend \%-50\%) }}\end{array}$ \\
\hline Oak vs. Pine & 11.62 & 841 & $64.4 \%$ & 167.3 \\
Pine vs. Juniper & 10.31 & 841 & $59.9 \%$ & 101.9 \\
Oak vs. Juniper & 9.87 & 886 & $59.2 \%$ & 90.9 \\
Juniper vs. Cedar & 7.42 & 619 & $67.6 \%$ & 130.8 \\
Oak vs. Cedar & 5.92 & 619 & $57.6 \%$ & 45.0 \\
Pine vs. Cedar & 4.59 & 619 & $58.6 \%$ & 39.4 \\
& & & & \\
\hline
\end{tabular}

Figure 3. Interspecies crossdating among Aegean forests spanning the last 6 to 8 centuries. The t-score is the most helpful diagnostic tool to help find a fit.

Observe that cedar is the most difficult of all (and has weaker statistics), partly because of the way cedars grow. In a worst-case scenario, on a piece of cedar from the forest at Bcharré in Lebanon, where multiple interventions by the villagers have damaged the trees heavily, one ring was present as two rows of six cells on a single radius (discovered by $\mathrm{R}$. Touchan), and then nothing at all on the rest of the cross-section. Cedars and junipers are often found growing together in the same forest, and we often use the less-erratic junipers as a corrective to look for and identify absent or partially absent rings on the cedars. What we seem to have here is a regional climate signal rather than just a species signal (Hughes et al. 2001).

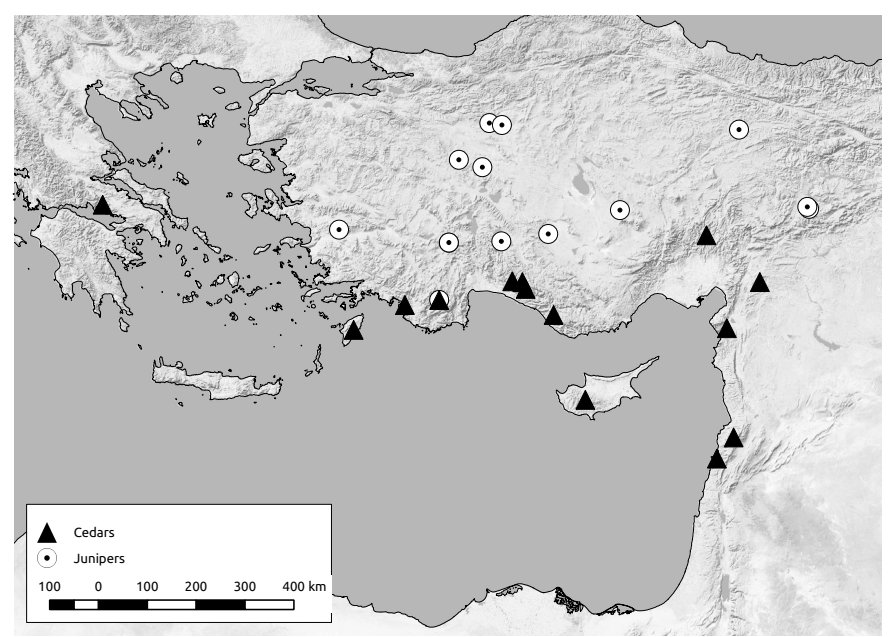

Figure 4. The map above of juniper and cedar forests (after Newton 2004) shows how far apart some of these trees grew. Maximum distances are over $1000 \mathrm{~km}$. That there is any fit at all among the data sets is highly satisfying.

\section{Why Use "Floating" or "Near-Absolute" for Our Chronology?}

Again, in a perfect world we would have an unbroken chain of tree-ring measurements from today back to the Bronze Age. Alas, in the centuries on either side of the year 1, we have a major gap, although a forthcoming publication addresses the substantial progress we have been making (Kuniholm et al., in press).

Until the links to the living trees of today are firmly established, we have had (and continue to have) to rely on ${ }^{14} \mathrm{C}$ wiggle-matching 
of specifically selected decadal samples from this long chronology. Our first attempt, reported in Nature (Kuniholm et al. 1996), placed the recent end of it in $718 \mathrm{BC}$ with an unacceptably high error margin of $+76 /-22$ years. The next summer, Bernd Kromer in Heidelberg showed Kuniholm how his continued determinations on our wood matched the morphology of the master ${ }^{14} \mathrm{C}$ curve so well that they forced us to move our chronology back 22 years so that it ended in 740 BC. This was reported in Science with a small error margin of $+4 /-7$ years (Manning et al. 2001; and the companion piece by Kromer et al. 2001). Subsequently, as reported in Antiquity (Manning et al. 2003) the error margin is reducible to 1-3 years. The dendrochronological dates quoted herein are cited without this error margin. This is a bit of the history of the "floating, near-absolute" chronology against which anything Egyptian is to be fitted. In all of this, the tree-ring chronology itself did not change, but its placement has varied as the new ${ }^{14} \mathrm{C}$ dates came in.

\section{The "Egyptian" Cedarwood Story that Future Researchers Need to Know}

Years ago, we measured two Egyptian cedarwood objects of some mild interest: one was the Oriental Institute's coffin of a certain Ipy-ha-Ishutef, the Army clerk (Egyptological colleagues tell us that "clerk" was perhaps something more like the Minister of Defense), and the second was the "Dahshur boat" in the Carnegie Mellon Museum in Pittsburgh, both recently ${ }^{14} \mathrm{C}$ dated and discussed in some detail by Manning et al. (2014).

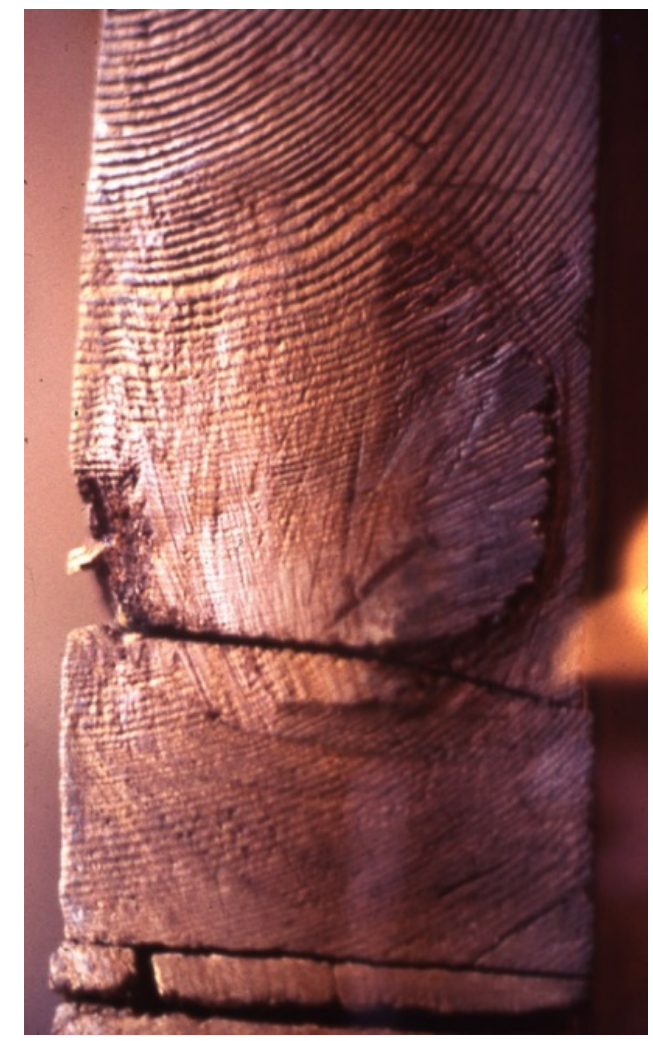

These two objects provide a lesson in the problematic nature of dating such material and illustrate the issues for publication of any dates found. In 2000, an obligatory annual report on the year's work to the Turkish General Directorate of Antiquities and Museums, and published by them a year later (Kuniholm 2001) in their Arkeometri Sonuçları Toplantısı (Meeting on the Results of Archaeometric Research), reported the following:

"The most significant development of the year was a test puttingtogether of 14 long tree-ring chronologies for the Early Bronze Age and the Middle Bronze Age, listed below in order by their starting date. These placements are still provisional, but they are worth reporting here simply because of the amount of time they cover-from 2944 B.C. to 627 B.C."

And then, after a tabulation of what we then thought we had, including the sarcophagus of Ipy in Chicago at $2286 \mathrm{BC}$ and the Dahshur boat in Pittsburgh at 2104 BC, the report continued:

"We thus have a ring-sequence of 1201 years for the EBA/ MBA, extending from 2944 B.C. to 1744 B.C. I concede, as I said at the outset, that the beginning is based on very short overlaps. When more EBA wood appears, it will be entertaining to see whether this proposed placement is correct."

Subsequently - that very year-we went back to the drawing board (literally: we were using paper graphs) to try the exercise all
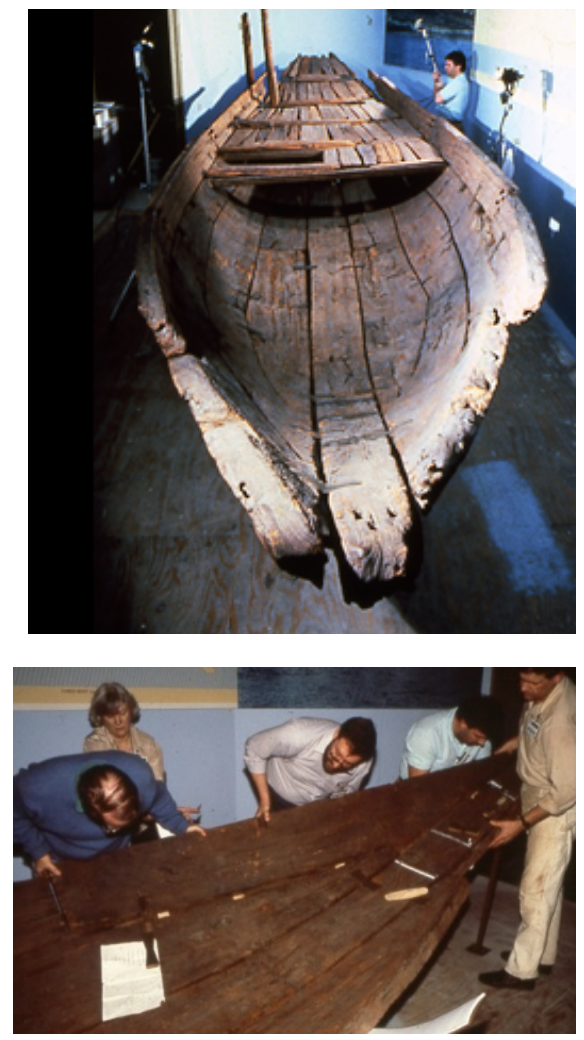

Figure 5. The end grain of part of the lid of Ipy's coffin (left) as seen in the vitrine in Chicago and the Dahshur boat during reassembly (right below) in Pittsburgh and after reassembly (right above). The hull timbers of the latter were carved to shape rather than bent. One of the deck-planks amidship with $400+$ rings showed cuttings from reuse. 
over again, as one always does in such a case where the sequences are short and the crossmatching tentative. Eventually, starting in 2000, we found much better visual and statistically significant placements for the two sets of ring series from both Ipy's coffin and the Dahshur boat as explained below.

This work put the sarcophagus of Ipy at 2076 BC [right in the middle of a recently proposed $2 \sigma{ }^{14} \mathrm{C}$ range of $2081-2063 \mathrm{BC}$ (Manning et al. 2014)] and the Dahshur boat at 1883 BC [2 years outside the Manning et al. (2014) proposed $2 \sigma$ range of 1898$1885 \mathrm{BC}$. Because no terminal rings or waney edges are present on either the coffin or the boat, these are terminus post quem dates. They are dendrochronological placements, not against the big master chronologies from Kültepe and Acemhöyük, etc., but rather against some of the subsets of timbers that apparently came from different forests than timbers found in the adjacent rooms of the same palace that make up the bulk of the chronology.

After work with the modern cedars of the Taurus and AntiTaurus is finished, we plan to return to the task of sorting out the various subsets of the Bronze Age cedars and their possible provenience(s). We note — on the basis of Kuniholm's and Newton's experience in building the Anatolian chronology - that the first steps will be the hardest. As more measured objects are added to the corpus, the easier it should get.

\section{Why Were the New Findings Not Published?}

One might reasonably ask why we did not rush into print with our revised dendrochronological results back in 2004 and 2005. First of all, the sarcophagus of Ipy-bought in the Cairo bazaar and thus without any stratigraphic context or legitimate provenience-remains unpublished after a century in Chicago. The ticket on it says "Dynasty 9/10," which could mean anywhere between 2160 and 2025 BC (Shaw 2000b:480). Secondly, the total documentation for the Dahshur boat is a telegram to the CarnegieMellon Museum from Mr. Andrew Carnegie in Egypt — which we were shown at the time we drilled the samples - that says, "AM SENDING BOAT," although Jacques de Morgan may have seen the boat along with several other boats at Dahshur (and now see Patch and Haldane 1990). Thus, because these were two relatively isolated items of uncertain ancestry, it seemed pointless to continue announcing anything until additional late-3rd millennium or early 2nd-millennium wood came into the lab-which, although we expected it at the time, did not happen before Newton left in 2006 and Kuniholm retired - to confirm our findings. Thirdly, the overlaps, as noted in the captions to Figures 6 and 7, are very short. We did summarize the state of play in Anatolia in late 2004 in the Braidwood Memorial Volume of TÜBA-AR (Newton and Kuniholm 2004) without mentioning the Egyptian material that seemed irrelevant for a paper whose focus was Bronze Age Anatolia. Then, there is the issue of reuse: we had the once-in-a-lifetime opportunity to examine all six sides of each piece of wood that was part of the Pittsburgh boat before drilling it at a right angle to the ring growth. Cheryl Ward, who was working with us, recorded the curvature of the rings (Haldane 1984). Curiously enough, the timbers were not bent to shape but rather carved or adzed to shape the way one might carve up a watermelon. There must have been an extraordinary wastage of this valuable wood with "planks" as long as $4.19 \mathrm{~m} \times 12 \mathrm{~cm}$ thick $\times 35.5 \mathrm{~cm}$ wide (Patch and Haldane 1990). Ward also made an attempt to line up knots and other features so that she could determine which timbers might have been from the same tree. We were keenly aware that there was the possibility of reuse, but there was not one single cutting to suggest any prior use for any of the hull timbers. One deck plank with some 400-odd rings, however, did show a number of cuttings indicating a prior existence and use. It does not crossdate with the hull timbers. Living cedars in the Taurus Mountains of the size of these hull timbers have diameters of over $2 \mathrm{~m}$, and ages range up to $700+$ years. So we feel that PIT-1A and PIT-21A with their ring curvatures tighter than the rest of the hull samples represent the inner rings of very long-lived trees.

What the confirmed dates (dendrochronology plus ${ }^{14} \mathrm{C}$ ) show is that crossdating between cedars and junipers from a variety of forests in the Taurus Mountains (as represented by the timbers excavated at Kültepe/Acemhöyük/Karahöyük-Konya) and imported cedarwood and juniper found in Egypt is sometimes possible, although not always straightforward or easy. Thus, the Anatolian sequences can be used to date the imports as Lorentzen

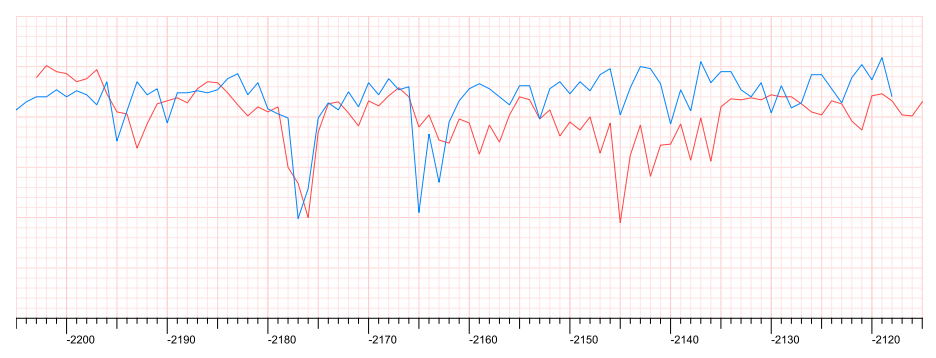

Figure 6. Screen shot of the visual fit between Kültepe 85 (in blue) and Chicago $4 \& 5$ (Ipy, in red) as we placed them 10 years ago with the latter ending at $2076 \mathrm{BC}$. Although the t-score is 4.12 and the r-score is 0.41 , the overlap is only 86 years, and the trend coefficient is poor, so we held off announcing anything until something better came along. We believe the source of these timbers is probably different from the rest of the KUL material.

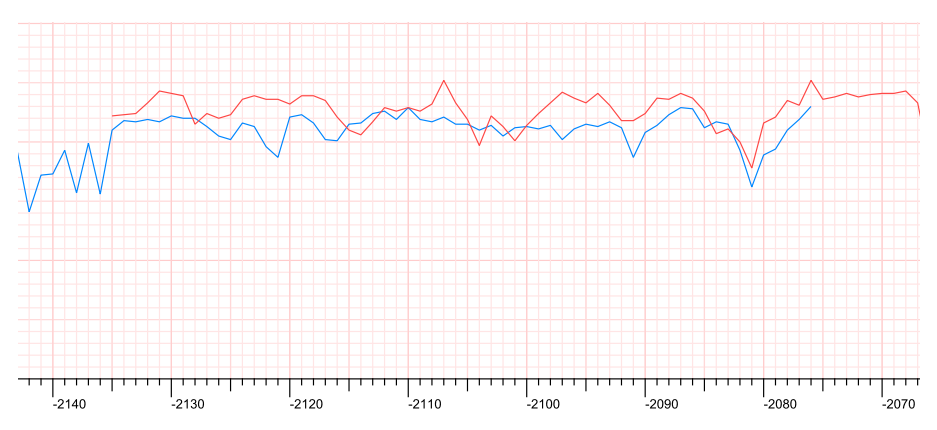

Figure 7. Screen shot of CHI4\&5.14C (Ipy, in blue) date-stamped 10/18/05 versus PIT555.mwn (Dahshur, in red) date-stamped 06/02/04 with the last ring of the former at $2076 \mathrm{BC}$ and the last ring of the latter at $1884 \mathrm{BC}$ plus one unmeasured ring, thus $1883 \mathrm{BC}$. The $\mathrm{t}$-score is $3.09, \mathrm{n}=61$ years, $\mathrm{r}$-score is 0.38 , but the trend coefficient is poor. We suspected at the time a missing-ring problem but could not prove it with the then available material. 
has now found for the Ottoman structures in the southern Levant. The dendrochronological potential for imported cedarwood found in Egypt is more exciting - even if challenging - than ever, and future workers will have a lot of data-some absolutely placed in time, some near-absolutely - to which to refer as they collect and measure more Egyptian material.

\section{SUMMARY}

This account highlights - and this cannot be emphasized too strongly - a difficulty inherent with dendroarchaeological procedure, namely that our work is subject to the limitations of what the archaeological record provides and the material we gain permission to sample, not necessarily in any logical or helpful order. Unlike our dendrochronological colleagues who work with forest materials, we cannot plan a sampling strategy and produce a publication based on these results. Instead, we have worked with difficult material as it emerged from the ground or from the museums and we have tried to provide the best information we couldand as promptly as possible - for our archaeological colleagues and the permission-granting authorities. One European colleague suggested that we publish nothing on cedar - of which we had some 4000 years' worth already in hand - until the chronology was complete and all the problems were worked out, but this was an unrealistic proposition.

The dates of 2076 BC for Ipy's coffin and 1883 BC for the Dahshur boat - a combination of our 2004/2005 dendrochronological placements as supported by the 82 newly announced ${ }^{14} \mathrm{C}$ determinations of Manning et al. (2014) — offer a satisfying prospect for future investigation of imported cedarwood found in secure contexts in Egypt. Although at this time there are no Bronze Age tree-ring chronologies for either Lebanon or Cyprus, living trees from the latter crossdate splendidly with the Taurus Mountains only $60 \mathrm{~km}$ away, so unless the climate was radically different from today's - for which there is no evidence - the Bronze Age material should crossdate, too. Thus, anything imported into Egypt from the Taurus or the Anti-Taurus or Cyprus, or possibly north Lebanon itself, ought to be datable against our master chronology, which spans the early 1st millennium $\mathrm{BC}$, the entire 2nd millennium BC, and most of the 3rd (Kuniholm et al. 2005). These chronologies, both absolute and near-absolute, are available to the next generation of workers as it begins its new work.

There are other obstacles that will no doubt slow the expansion of the dendrochronological technique in Egypt. One is the simple fact that many Egyptian scholars are unfamiliar with the methods and potential of modern dendroarchaeology. Publishing articles and fundamental books in dendrochronology in Arabic would be a good first step toward introducing the science of dendrochronology to Egyptian scholars, Egyptologists, and other scientists, professionals, and a variety of authorities, and students across the Arabic-speaking world.

We need to provide training and hold workshops for Egyptian archaeologists, especially field archaeologists who may encounter material during excavations, to help them understand the principles of dendrochronology and how to identify good samples and submit them for analysis. Because current Egyptian law prevents the transfer of artifacts abroad, there is a real need to start a laboratory of tree-ring research in Egypt - perhaps attached to the relevant department(s) in the Faculty of Sciences and the Faculty of Archaeology at Cairo University - and to work in coordination with other laboratories of tree-ring research. ${ }^{11}$ Ideally, the academic program in this new department should be interdisciplinary, combining Egyptian material culture, sciences, and statistics. Egyptian antiquities laws would also spur new technical developments in the field of dendrochronology itself. Under present regulations, no coring can be carried out on wooden material in Egypt. Further development or improvement of scanning or photograph-based methods would advance dendrochronological work in Egypt, enabling studies to progress without harming any of the more sensitive items of material culture (Mitsutani 2004).

\section{ACKNOWLEDGMENTS}

This work was supported by the National Science Foundation, The National Endowment for the Humanities, The National Geographic Society, The Malcolm H. Wiener Foundation, The Samuel H. Kress Foundation, The Packard Humanities Institute, The Wenner-Gren Foundation, Cornell University, The University of Arizona, and individual Patrons of our project. We thank the relevant permission-granting archaeological institutions of the countries in which we work and the excavators and museum officials who make us welcome year after year. Finally, we thank our four anonymous reviewers for their criticisms and suggestions.

\section{REFERENCES}

Arnold, Di., 1991. Building in Egypt: Pharaonic Stone Masonry. Oxford University Press, Oxford.

Arnold, Do., 2001. Holzdächer spätzeitlicher ägyptischer Tempel. In Archaische griechische Tempel und Altägypten: Internationales Kolloquium am 28. November 1997 am Institut für Ägyptologie der Universität Wien, edited by M. Bietak; pp. 107-115. Österreichischen Akademie der Wissenschaften, Vienna.

Bannister, B., 1962. The interpretation of tree-ring dates. American Antiquity 27(4):508-514.

Bannister, B., 1963. Dendrochronology. In Science in Archaeology. Fifty-Five International Authorities Present the Definitive Sourcebook of Method and Technique, edited by D. Brothwell and E. Higgs; pp. 162-176. Basic Books, New York.

Bannister, B., 1970. Dendrochronology in the Near East. Current research and future potentialities. Proceedings of the Seventh International Congress of Anthropological and Ethnological Sciences, Moscow, 1964 5:336-340. Reprinted. Tree-Ring Bulletin 1997, Special Issue.

Bannister, B., and Robinson, W. J., 1975. Tree-ring dating in archaeology. World Archaeology 7(2):210-225.

11. Aside from the Chicago coffin and the Pittsburgh boat, most dendrochronological studies of Egyptian cedar have been made on objects sampled 8 decades ago at the Boston Museum of Fine Arts thanks to Dows Dunham, notably the finds from Dayr el-Bershah. Kuniholm and Newton have analyzed cores from Tomb 10A, that of a local governor Djehutynakht and his wife (also named Djehutynakht). We now have crossdates for three planks and are working on the rest. If ${ }^{14} \mathrm{C}$ tests confirm the dendrochronological results - with multiple pieces and at least 222 years of overlap, possibly more - we expect to be able to report the dendrochronological dates next year. 
Bannister, B., and Robinson, W. J., 1992. Archaeology and dendrochronology. In Emil W. Haury's Prehistory of the American Southwest, edited by J. J. Reid, and D. E. Doyel; pp. 49-54. University of Arizona Press, Tucson.

Bannister, B., R. E. Hastings, Jr., and J. Banister, 1998. Remembering A. E. Douglass. Journal of the Southwest 40(3):307-318.

Bassir, H., 2012. Egypt. Pharaohs, kings and presidents. In The Histories of Nations. How Their Identities Were Forged, edited by P. Furtado; pp. 19-25. Thames \& Hudson, New York.

Bassir, H., 2013. The Grand Egyptian Museum. A home for interconnections. Journal of Ancient Egyptian Interconnections 5(4):6-8.

Baum, N., 1988. Arbres et Arbustes de l'Egypt Ancienne. La Liste de la Tombe Thébaine d'Inéni (no 81). Peeters, Leuven.

Bronk Ramsey, C., 2013. Using radiocarbon evidence in Egyptian chronological research. In Radiocarbon and the Chronologies of Ancient Egypt, edited by A. J. Shortland, and C. Bronk Ramsey; pp. 29-39. Oxbow, Oxford.

Brown, J. P., 1969. The Lebanon and Phoenicia. Ancient Texts Illustrating Their Physical Geography and Native Industries. I. The Physical Setting and the Forest. American University of Beirut, Beirut.

Brunton, G., and G. Caton-Thompson, 1928. The Badarian Civilisation and Predynastic Remains near Badari. British School of Archaeology in Egypt, London.

Çevre ve Orman Bakanlığ [Ministry of the Environment and Forests], 19992003. Osmanlı Ormancllığ ile Illgili Belgeler [Ottoman Forestry Documents]. Çevre ve Orman Bakanlı̆̆ı, Ankara.

Cichocki, O., 2003. Dendrochronological investigations on cedar objects of ancient Egypt. In The Synchronisation of Civilisations in the Eastern Mediterranean in the Second Millennium B.C. II. Proceedings of the SCIEM 2000 - EuroConference, Haindorf, 2nd of May-7th of May 2001, edited by M. Bietak; pp. 43-46. Österreichischen Akademie der Wissenschaften, Vienna.

Cichocki, O., M. Bichler, G. Firneis, W. Kutschera, W. Müller, and P. Stadler, 2004. Synchronization of civilizations in the Eastern Mediterranean in the Second Millennium BC. Natural science dating. In Tools for Constructing Chronologies. Crossing Disciplinary Boundaries, edited by C. E. Buck, and A. Millard; pp. 83-109. Springer, London.

Cowie, J., 2013. Climate Change. Biological and Human Aspects, 2nd edition. Cambridge University Press, Cambridge.

Davies, W. V., 1995. Ancient Egyptian timber imports. An analysis of wooden coffins in the British Museum. In Egypt, the Aegean and the Levant. Interconnections in the Second Millennium BC, edited by W. V. Davies, and L. Schofield; pp. 146-156. British Museum, London.

Dean, J., 1978. Tree-ring dating in archaeology. In University of Utah Anthropological Papers: Misc. Paper 24, edited by J. Jennings; pp. 129-163. University of Utah Press, Salt Lake City.

Dean, J., 1996. Dendrochronology and the study of human behavior. In Tree Rings, Environment and Humanity. Proceedings of the International Conference, Tucson, Arizona 17-21 May 1994, edited by J. S. Dean, D. Meko, and T. W. Swetnam; pp. 461-469. Radiocarbon, Tucson.

Deglin, F., 2012. Wood exploitation in ancient Egypt: Where, who and how? In Current Research in Egyptology 2011. Proceedings of the Twelfth Annual Symposium Which Took Place at Durham University, United Kingdom, March 2011, edited by H. Abd El Gawad, N. Andrews, M. Correas-Amador, V. Tamorri, and J. Taylor; pp. 85-96. Oxbow, Oxford.

Douglass, A. E., 1929. The secret of the Southwest solved by talkative tree rings. National Geographic Magazine 56(6):736-770.

Dunwiddie, P. 1979. Dendrochronological studies of indigenous New Zealand trees. New Zealand Journal of Botany 17:251-266.

El Gabry, D., 2014. Chairs, Stools, and Footstools in the New Kingdom. Production, Typology, and Social Analysis. British Archaeological Reports, Oxford.

Engelbach, R., 1931. Ancient Egyptian woods. Annales du Service des Antiquités de l'Égypte 31:144.

Gale, R., P. Gasson, and N. Hepper, 2009. Wood. In Ancient Egyptian Materials and Technology, edited by P. T. Nicholson, and I. Shaw; pp. 334-352. Cambridge University Press, Cambridge.

Gilbert, A. S., 1995. The flora and fauna of the ancient Near East. In Civilizations of the Ancient Near East. I, edited by J. M. Sasson; pp. 153-174. Charles Scribner's Sons, New York.

Greiss, E. A. M., 1957. Anatomical Identification of Some Ancient Egyptian Plant Materials. C. Tsoumas, Cairo.

Haldane, C. W., 1984. The Dashur Boats. Unpublished M.A. thesis. Texas A \& M
University, College Station, TX

Hannig, R., 2006. Großes Handwörterbuch Ägyptisch-Deutsch (2800-950 v. Chr.). Die Sprache der Pharaonen. Phillip von Zabern, Mainz.

Harvey, J., 2001. Wooden Statues of the Old Kingdom. A Typological Study. Brill, Leiden.

Haury, E. W., 1935. Tree rings. The archaeologist's time-piece. American Antiquity 1(2):98-108.

Haury, E. W., 1962. HH-39: Recollections of a dramatic moment in Southwestern archaeology. Tree-Ring Bulletin 24(3-4):11-14.

Haury, E. W., 1994. HH-39: Recollections of a dramatic moment in Southwestern archaeology. In Emil W. Haury's Prehistory of the American Southwest, edited by J. J. Reid, and D. E. Doyel; pp. 55-60. University of Arizona Press, Tucson.

Hepper, F. N., 1990. Pharaoh's Flowers. The Botanical Treasures of Tutankhamun. KWS Publishers, London.

Hepper, F. N., 1996. Timber trees of western Asia. In The Furniture of Western Asia, Ancient and Traditional. Conference at the Institute of Archaeology, University College London, June 28 to 30, 1993, edited by G. Herrmann; pp. 1-12. Phillip von Zabern, Mainz.

Hornung, E., R. Krauss, and D. A. Warburton, editors, 2006. Ancient Egyptian Chronology. Brill, Leiden.

Hughes, M. K., P. I. Kuniholm, J. Eischeid, G. Garfin, C. B. Griggs, and C. Latini, 2001. Aegean tree-ring signatures explained. Tree-Ring Research 57(1):6773

Judd, N. M., 1962. Andrew Ellicott Douglass 1867-1962. American Antiquity 28(1):87-89.

Killen, G., 1994a. Ancient Egyptian Furniture. II. Boxes, Chests and Footstools. Aris \& Phillips, Warminster.

Killen, G., 1994b. Egyptian Woodworking and Furniture. Shire, Princes Risborough, UK.

Killen, G., 1996. Le travail du bois et ses techniques dans l'Égypte ancienne. Translated by A. Berthoin-Mathieu. Égypte, Afrique \& Orient 3:2-7.

Killen, G., 2001. Woodworking. In The Oxford Encyclopedia of Ancient Egypt. III, edited by D. B. Redford; pp. 516-519. Oxford University Press, New York.

Killen, G., 2009. Wood. In Ancient Egyptian Materials and Technology, edited P. T. Nicholson, and I. Shaw; pp. 353-367. Cambridge University Press, Cambridge.

Kitchen, K. A., 2013. Establishing chronology in Pharaonic Egypt and the ancient Near East. Interlocking textual sources relating to c. 1600-664 BC. In Radiocarbon and the Chronologies of Ancient Egypt, edited by A. J. Shortland, and C. Bronk Ramsey; pp. 1-18. Oxbow, Oxford.

Kromer, B., S. W. Manning, P. I. Kuniholm, M. W. Newton, M. Spurk, and I. Levin, 2001. Regional ${ }^{14} \mathrm{CO}_{2}$ gradients in the troposphere: Magnitude, mechanisms and consequences. Science 294(5551):2529-2532.

Kuniholm, P. I., 1977. Dendrochronology at Gordion and on the Anatolian Plateau. Unpublished Ph.D. dissertation. University of Pennsylvania, Philadelphia.

Kuniholm, P. I., 1996. The prehistoric Aegean. Dendrochronological progress as of 1995. Acta Archaeologica 67:327-335.

Kuniholm, P. I., 1997. Wood. In The Oxford Encyclopedia of Archaeology in the Near East, edited by E. M. Meyers; pp. 347-349. Oxford University Press, Oxford.

Kuniholm, P. I., 2000. Dendrochronologically dated Ottoman monuments. In Breaking New Ground for an Archaeology of the Ottoman Empire, edited by U. Baram and L. Carroll; pp. 93-136. Springer, New York.

Kuniholm, P. I., 2001. Aegean Dendrochronology Project. 1999-2000 results. In Proceedings of the XXIInd Symposium on Excavation, Research and Archaeometry (Izmir, May 2000); pp. 79-84. Türk Tarih Kurumu Basımevi, Ankara.

Kuniholm, P. I., 2002. Dendrochronological investigations at Herculaneum and Pompeii. In The Natural History of Pompeii, edited by W. F. Jashemski, and F. G. Meyer; pp. 235-239. Cambridge University Press, Cambridge.

Kuniholm, P. I., and M. W. Newton, 1990. A 677 year long tree-ring chronology for the Middle Bronze Age. In Anatolia and the Ancient Near East. Studies in Honor of Tahsin Özgüç, edited by K. Emre, M. Mellink, B. Hrouda, and N. Özgüç; pp. 279-293. Türk Tarih Kurumu Basımevi, Ankara.

Kuniholm, P. I., and M. W. Newton, 2011. Dendrochronology at Gordion. In The New Chronology of Early Iron Age Gordion, edited by C. B. Rose, and G. Darbyshire; pp. 79-122. University of Pennsylvania Press, Philadelphia.

Kuniholm, P. I., and C. L. Striker, 1987. Dendrochronological investigations in the Aegean and neighboring regions, 1983-1986. Journal of Field Archaeology 14(4):385-398. 
Kuniholm, P. I., B. Kromer, S. W. Manning, M. Newton, C. E. Latini, and M. J. Bruce, 1996. Anatolian tree rings and the absolute chronology of the Eastern Mediterranean, 2220-718 BC. Nature 381(6585):780-783.

Kuniholm, P. I., M. W. Newton, C. B. Griggs, and P. J. Sullivan, 2005. Dendrochronological dating in Anatolia. The Second Millennium B.C. significance for early metallurgy. In Anatolia III, Der Anschnitt, Beiheft 18, edited by Ü. Yalçın; pp. 41-47. Deutsches Bergbau-Museum, Bochum.

Kuniholm, P. I., C. B. Griggs, M. W. Newton, 2007. Evidence for early timber trade in the Mediterranean. In Byzantina Mediterranea. Festschrift für Johannes Koder zum 65. Geburtstag, edited by K. Belke, E. Kisslinger, A. Külzer, and M. A. Stassinopoulou; pp. 365-385. Böhlau, Vienna.

Kuniholm, P. I., C. L. Pearson, T. J. Wazny, and C. B. Griggs, in press. A 2367-year oak tree-ring chronology from 98 sites for the Aegean, East Mediterranean, and Black Seas. The Marmaray contribution. In Istanbul and Water. Ancient Near Eastern Studies Supplement 47, edited by P. Magdalino, and N. Ergin. Peeters, Leuven.

Lorentzen, B., 2013. Variability in Levantine Tree-Ring Records and Its Applications in Dendrochronological Dating, Provenancing, and Paleoenvironmental Reconstruction in the Southern Levant. Unpublished Ph.D. dissertation. Cornell University, Ithaca.

Lorentzen, B., P. I. Kuniholm, and T. Wazny, in press. Chapter 23. Dendrochronological Dating and Provenancing of the Late Ottoman Buildings. In Excavations at the Kishle Site, Yafo, edited by Y. Arbel. The Jaffa Cultural Heritage Project. Cotsen Institute of Archaeology, Los Angeles.

Lorentzen, B., P. I. Kuniholm, T. Wazny, M. Bernabei, C. B. Griggs, and J. Bontadi, 2011. Identifying imported European and North Mediterranean timber use and non-use in the southern Levant through dendro-provenancing. Poster presented at Eurodendro 2011, Engelberg, Switzerland, September 19-23, 2011.

Lorentzen, B., P. I. Kuniholm, and T. Wazny, 2012. Cedar of Lebanon (made in Anatolia). Reconstructing Late Ottoman timber trade networks with dendrochronology and dendroprovenancing. Presentation given at Annual Meeting of the Association of American Geographers, New York, February 24-28, 2012.

Lucas, A., and J. R. Harris, 1962. Ancient Egyptian Materials and Industries. Kessinger Publishing, London.

Manning, S. W., B. Kromer, P. I. Kuniholm, M. W. Newton, 2001. Anatolian treerings and a new chronology for the East Mediterranean Bronze-Iron Ages. Science 294(5551):2532-2535.

Manning, S. W., B. Kromer, P. I. Kuniholm, and M. W. Newton, 2003. Confirmation of near-absolute dating of East Mediterranean Bronze-Iron dendrochronology. Antiquity 77(295). http://antiquity.ac.uk/ProjGall/Manning/manning.html.

Manning, S. W., M. W. Dee, E. M. Wild, C. Bronk Ramsey, K. Bandy, P. P. Creasman, C. B. Griggs, C. L. Pearson, A. J. Shortland, and P. Steier, 2014. High-precision dendro- ${ }^{14} \mathrm{C}$ dating of two cedar wood sequences from First Intermediate Period and Middle Kingdom Egypt and a small regional climate-related ${ }^{14} \mathrm{C}$ divergence. Journal of Archaeological Science 46:401-416.

Meiggs, R., 1982. Trees and Timber in the Ancient Mediterranean World. Oxford.

Mikhail, A., 2011. Nature and Empire in Ottoman Egypt. An Environmental History. Cambridge University Press, Cambridge.

Mitsutani, T., 2004. Dendrochronology and the Latest Imaging Equipments [sic]. Applications to Ancient Architecture, Carved Wooden Buddha Statues, and Wooden Artifacts. National Research Institute for Cultural Properties, Nara.

Nash, S. E., 1998. Time for collaboration. A. E. Douglass, archaeologists, and the establishment of tree-ring dating in the American Southwest. Journal of the American Southwest 40(3):261-305.

Nash, S. E., 1999. Time, Trees, and Prehistory. Tree-Ring Dating and the Development of North American Archaeology, 1914 to 1950. University of Utah Press, Salt Lake City.

Nash, S. E., 2008. Seven decades of archaeological tree-ring dating. In It's About Time. A History of Archaeological Dating in North America, edited by S. E. Nash; pp. 60-83. University of Utah Press, Salt Lake City.

Nash, S. E., and J. S. Dean, 2005. Paleoenvironmental reconstructions and archaeology. Uniting the social and natural sciences in the American Southwest and beyond. In Southwest Archaeology in the Twentieth Century, edited by L. S. Cordell, and D. D. Fowler; pp. 125-141. University of Utah Press, Salt Lake City.
Newton, M. W., 2004. Selected Problems in Aegean and Near Eastern Dendrochronology. Unpublished Ph.D. dissertation, Cornell University, Ithaca.

Newton, M. W., and P. I. Kuniholm, 2004. A dendrochronological framework for the Assyrian colony period in Asia Minor. In TÜBA-AR 10: Featuring Complex Societies from Early Villages to Early Towns. Studies in Memory of Robert J. Braidwood; pp. 165-176. Turkish Academy of Sciences, Ankara.

Nibbi, A., 1981. Ancient Egypt and Some Eastern Neighbors. Noyes, Park Ridge, NJ.

Nibbi, A., 1987. Some remarks on the lexicon entry. Zeder, cedar. Discussions in Egyptology 7:13-27.

Nibbi, A., 1990. A note on the cedarwood from Maadi. Discussions in Egyptology 17:25-27.

Oakley, K. P., 1932. Woods used by the ancient Egyptians. Analyst 57(672):158-159.

Patch, D. C., and C. W. Haldane, 1990. The Pharaoh's Boat at the Carnegie. Carnegie Museum of Natural History, Pittsburgh.

Postgate, J. N., and M. Powell, editors, 1992. Trees and Timber in Mesopotamia. Sumerian Agriculture Group, Cambridge.

Reid, J. J., and S. M. Whittlesey, 2005. Seven years that reshaped Southwest prehistory. In Southwest Archaeology in the Twentieth Century, edited by L. S. Cordell and D. D. Fowler; pp. 47-59. University of Utah Press, Salt Lake City.

Rich, S., 2013. Ship Timber as Symbol? Dendro-Provenancing and Contextualizing Ancient Cedar Ship Remains from the Eastern Mediterranean/Near East. Unpublished Ph.D. dissertation. KU Leuven. Leuven.

Rizkana, I., and J. Seeher, 1989. Maadi III. The Non-Lithic Small Finds and the Structural Remains of the Predynastic Settlement. Phillip von Zabern, Mainz.

Ryholt, K. S. B., 1997. The Political Situation in Egypt during the Second Intermediate Period c. 1800-1550 B.C. Museum Tusculanum Press, Copenhagen.

Schweingruber, F. H., 1988. Tree Rings. Basics and Applications of Dendrochronology. Carsten Niebuhr Institute of Near Eastern Studies, Copenhagen.

Shaw, I., 2000a. Introduction. Chronologies and cultural change in Egypt. In The Oxford History of Ancient Egypt, edited by I. Shaw; pp. 1-16. Oxford University Press, Oxford.

Shaw, I., editor, 2000b. The Oxford History of Ancient Egypt. Oxford University Press, Oxford.

Sowada, K. N., 2009. Egypt in the Eastern Mediterranean during the Old Kingdom. An Archaeological Perspective. Academic Press, Fribourg.

Speer, J. H., 2010. Fundamentals of Tree-Ring Research. University of Arizona Press, Tucson.

Thirgood, J. V., 1981. Man and the Mediterranean Forest. A History of Resource Depletion. Academic Press, London.

Touchan, R., and M. K. Hughes, 2009. Dendroclimatology in the Near East and the Eastern Mediterranean Region. In Tree-Rings, Kings and Old World Archaeology and Environment. Papers Presented in Honor of Peter Ian Kuniholm, edited by S. W. Manning, and M. J. Bruce; pp. 65-70. Oxbow, Oxford.

Touchan, R., D. Meko, and M. K. Hughes, 1998. A 396-year reconstruction of precipitation in southern Jordan. Journal of the American Water Resources Association 35(1):49-59.

Turkish Forestry Research Institute, 1990. International Cedar Symposium, 22 27 October, 1990, Antalya, Secretariat of the Organizing Committee, Orman Bakanlığı, Ankara.

Ward, C., 2000. Sacred and Secular. Ancient Egyptian Ships and Boats. Archaeological Institute of America, Boston.

Ward, C., 2006. Boat-building and its social context in early Egypt. Interpretations from the First Dynasty boat-grave cemetery at Abydos. Antiquity 80(307):118-129.

Ward, C., and C. Zazzaro, 2010. Evidence for Pharaonic seagoing ships at Mersa/ Wadi Gawasis, Egypt. International Journal of Nautical Archaeology 39(1):27-43.

Webb, G. E., 1983. Tree Rings and Telescopes. The Scientific Career of A. E. Douglass. University of Arizona Press, Tucson.

Wilson, P., 1997. A Ptolemaic Lexikon. A Lexicographical Study of the Texts in the Temple of Edfu. Peeters, Leuven.

Wittmack, L., 1912. Holz vom Porträtkopf der altägyptischen Königin Teje (18. Dynastie, ca. 1400 v. Chr.). Berichte der Deutschen Botanischen Gesellschaft $30: 275-278$. 